\title{
Legality as separation of powers
}

Article

Accepted Version

Lakin, S. (2017) Legality as separation of powers.

Jurisprudence, 8 (3). pp. 653-659. ISSN 2040-3321 doi:

https://doi.org/10.1080/20403313.2017.1385298 Available at https://centaur.reading.ac.uk/66448/

It is advisable to refer to the publisher's version if you intend to cite from the work. See Guidance on citing.

To link to this article DOI: http://dx.doi.org/10.1080/20403313.2017.1385298

Publisher: Taylor \& Francis

All outputs in CentAUR are protected by Intellectual Property Rights law, including copyright law. Copyright and IPR is retained by the creators or other copyright holders. Terms and conditions for use of this material are defined in the End User Agreement.

\section{www.reading.ac.uk/centaur}

\section{CentAUR}

Central Archive at the University of Reading

Reading's research outputs online 


\title{
Legality as Separation of Powers
}

\author{
Stuart Lakin*
}

\section{INTRODUCTION}

Why and how are the past decisions of legislatures, courts, and other political institutions relevant to the content of the law in a given political community? For legal interpretivists, this is a thoroughgoing moral question. ${ }^{1}$ If (say) parliamentary enactments contribute to the law, they do so only in virtue of some justifying political principles such as democracy, authority, or legal certainty. Those principles will determine which aspect of the statute is legally relevant - whether, for instance, it is the literal meaning of the text, the intentions of the legislator, particular moral principles or something else. And those principles may rule out certain purported statutes as genuine contributions to the law. By approaching legal theory in this way, interpretivists connect arguments about law and legality to broader questions of political legitimacy and constitutional theory: what justifies the power of the state to alter our pre-existing moral rights and duties? What are the limits of that power? Do we have a general moral obligation to obey the decisions of political institutions, including decisions that seem to us unfair or unjust? Who is 'we' and 'our'??

In Shared Authority, Dimitrios Kyritsis offers a sophisticated set of responses to these types of questions. He does so using a two-pronged strategy. On the one hand, he defends the interpretative tradition against those who reject it altogether, most notably Joseph Raz. ${ }^{3}$ On the other hand, he crafts a careful revision of the celebrated interpretative theory of Ronald Dworkin, law as integrity. ${ }^{4}$ His focus in each case is the way in which Raz and Dworkin conceive of the relationship between courts and legislatures. While Kyritsis is firmly in the anti-positivist camp, his revised interpretivism owes considerable debts to legal positivism. ${ }^{5}$ Indeed, his book provides a much-needed bridge between these two rather polarised traditions in legal philosophy. There are countless potential talking points in Shared Authority, but in this short review I shall focus on the relationship he envisages between legality as separation of powers and justice. Notwithstanding the depth and rigour of his arguments on this point, I shall tentatively suggest that Dworkin's account of legality as integrity is to be preferred. Before coming to my discussion, it will first be helpful to give an outline of the Kyritsis's main claims.

\section{KYRITSIS’S REVISED LEGAL INTERPRETIVISM}

Let us return to the question posed at the outset: why and how are the past decisions of legislatures, courts, and other political institutions relevant to the content of the law in a given political

\footnotetext{
* School of Law, University of Reading, UK. Email: S.J.Lakin@Reading.ac.uk

1 See, in general, Nicos Stavropolous, 'Legal Interpretivism' at http://plato.stanford.edu/entries/lawinterpretivist/ (last accessed 21 January, 2016).

${ }^{2}$ Kyritsis continually emphasises these connection. See, for example, pp 23-24. For another distinguished recent argument to the same effect, see TRS Allan, The Sovereignty of Law: Freedom, Constitution and Common Law, (Oxford, Oxford University Press, 2013).

${ }^{3}$ See chapter 2. See, for instance, Joseph Raz, 'Dworkin: A New Link in the Chain' (1986) 74 Cal L Rev 1103.

${ }^{4}$ See chapter 3 onwards. For Dworkin's theory of law as integrity, in particular, Ronald Dworkin, Law's Empire (London: Fontana, 1986) chs 6 and 7.

${ }^{5}$ In particular, he gives us a natural law twist on the positivist idea of Shared Cooperative Authority (117-132). For an earlier rendition of his argument, see Dimitris Kyritsis, 'What is Good about Legal Conventionalism' (2008) 14 Legal Theory 135. For the positivist version of this idea, see, for instance, Michael Bratman, 'Shared Cooperative Authority' (1992) 101 Philosophical Review 327; Scott Shapiro, Legality (Cambridge MA, Harvard University Press, 2011).
} 
community? For Kyritsis, such decisions are legally relevant in terms of their underlying 'considerations' (i.e. moral principles) of substantive justice and institutional design. The first type of consideration goes to the question: what ought we to do? The second type of consideration goes to the question: who are you to tell me what to do? (71) The content of the law depends on the 'correct mix' of these considerations. This is his answer to the 'how' part of the original question. What is the correct mix? It will depend, Kyritsis says, on a number of variables: the institutional practices of a particular legal system, the context of particular doctrinal disputes, and the epistemic abilities of different decision-makers (155-157). As he puts it, he 'wears his parochialism on his sleeve' (22). Note, however, that Kyritsis's parochialism relates principally to institutional considerations. Considerations of content, he says, belong to ideal political theory rather than the day-to-day contingencies of particular constitutional practices. ${ }^{6}$ We shall return to this apsect of his theory below.

As an interpretivist, Kyritsis's answer to the question of how past political decisions impact on the law must depend on the answer to the question of why they have such an impact. ${ }^{7}$ This is to say that some moral theory must make it the case that considerations of substantive justice and institutional design are constitutive of the law. What moral theory does Kyritsis offer? The combined considerations of institutional design and content, he tells us, structure the relationship between institutions in a special way. Each institution should be seen a co-participant in a 'Joint Project of Governing' (69-92 and chs 3 and 4). This is a collaborative project, which gives each political institution a moral duty to respect the decisions of every other. Citizens - most visibly the 'fussy' ones - are an integral part of that project (ch 5). At the heart of Kyritsis's legal interpretivism, then, is the idea of 'shared power'. The political concept he associates with that ideal is separation of powers:

\begin{abstract}
'A political community is legitimate when it establishes standing guarantees for the proper exercise of political power because these guarantees can convince the losing side in a political contest to submit to a policy to which it objects. We commonly group this form of guarantees under another classical political concept, namely separation of powers. This, I argue, is a concept our theory of law must be made sensitive to.' (17)
\end{abstract}

This connection between law, legitimacy and separation of powers marks several interesting point of departure from the work of Dworkin. First, Kyritsis jettisons Dworkin's 'court-centric' account (as he sees it) of legality in favour of a more expansive account (16). In addition to an adjudicative dimension of legality (the on-demand enforcement of rights and duties by courts), he emphasises a 'systemic' dimension, which includes the many 'under-enforced'8 mechanisms for checking the abuse of power (104-5). In his view, this wider understanding of legality not only gives a better account of separation of powers, more in keeping with the writings of Montesquieu (107); it also gives a better account of the proper scope of legal theory. Following Waldron, Kyritsis thinks that a comprehensive theory of law must have as much to say about the legislature - and indeed other agents of government - as courts (114-116). ${ }^{9} \quad$ Secondly, Kyritsis rejects Dworkin's value of integrity. It is this second departure from Dworkin's theory that will occupy us for the remainder of this review.

\title{
LEGALITY AS THE SEPARATION OF POWERS
}

The aim of interpretative theories of law, we have said, is to explain how and why past political decisions determine present legal rights, duties and powers. From the perspective of courts, such theories must explain how the law (or, more abstractly, the value of legality) constrains judges in their decision-making. If judges are free to 'gerrymander' the legal materials, or ignore them altogether,

\footnotetext{
${ }^{6}$ This is not to say that standards of content do not vary between different legal systems. See the discussion at 70.

${ }^{7}$ See Stavropoulos, above $\mathrm{n} 1$

8 This expression - and part of the inspiration for this argument - comes from L Sager 'Material Rights, Underenforcement, and the Adjudication Thesis' (2010) 90 Boston University Law Review 579.

9 Jeremy Waldron, Law and Disagreement, (Oxford, Oxford University Press, 1999) ch 2.
} 
then interpretivism fails: it is nothing more than a label for the judge's own theory of justice. ${ }^{10}$ From the perspective of citizens, interpretive theories of law must explain why citizens owe allegiance to institutional decisions that do not match their personal convictions about justice. One way of understanding these explanatory challenges is in terms of the distinctiveness of legality as a value: how are legal rights and duties distinct from the rights and duties we have as a matter of ideal justice? Kyritsis's answer to that question reveals one of his key intuitions in Shared Authority. Law, he says, is 'justice in an institutional context' (110). An interpreter may only depart from justice for separation of powers reasons of institutional design (111). A judge deciding a case must therefore make two discrete judgements: first, what does justice require? Secondly, are there institutional reasons for me not to decide in accordance with justice? It is only the second of those questions that ties the judge to institutional history (73). Judgements of justice are free-standing.

Does Kyritsis's dynamic between justice and separation of powers give a convincing model of legality? To use Dworkin's familiar terms, does his interpretative theory fit and justify modern legal systems? I think there may be reasons to answer these questions in the negative. Take a case between Doe and Roe concerning the common law tort of negligence. We need not make the example any more detailed than that. I do not have much to say about the institutional constraints facing the judges in this and every other case. Any plausible account of legal interpretivism will accept that judges must give effect to the separation of powers settlement within that legal system. It may be, for instance, that the decision to make people in Roe's category liable in negligence is one better made by the legislature (for reasons, say, of democracy or institutional expertise), in which case judges should refrain from finding against Roe. My interest is in the other side of the equation - the question of content - and in how content interacts with institutional considerations. On Kyritsis's view, the judge must initially decide whether Doe is entitled to damages for Roe's actions or omissions as a matter of justice wholesale. That decision is a condition precedent to examining any relevant institutional constraints: it is only once the judge has decided what justice requires that he can decide whether or not there are institutional reasons not to enforce justice.

That two-stage sequence of reasoning seems problematic to me. It seems to be at odds with practical common law reasoning in at least two respects. First, legal decisions typically reflects a single, seamless judgement about how considerations of substance and institutional design combine. There is little evidence of the deliberate trade-off that Kyritsis describes. It would surprising if a judge were to declare at the end part one of his judgment that Doe is entitled to damages as a matter of substance, only to declare at the end of part two that he is not so entitled as a matter of institutional design. Doe might understandably question whether the judge is abdicating his duty to enforce his substantive rights. ${ }^{11} \quad$ Secondly, I think there are difficulties with seeing common law reasoning as 'justice in an institutional context'. For Kyritsis, recall, a judge is only bound by the institutional principles embedded in past political decisions; his judgements of content are independent of what any judge or legislator may have decided in the past. That asymmetric relationship between content and institutional design hardly matches the way that the judge adjudicating the dispute between Doe and Roe will approach his task. His interest in past political decisions will not be confined to understanding who should decide the issue, the institutional question. He will also try to understand from the precedents who is entitled under the law to what, the question of content. He will look at how judges have reasoned on such issues as who owes whom a duty of care, the conditions of proximity, foreseeability, causation, damages, and so on. In other words, he will try to understand the particular conception of justice instantiated in past decisions. Imagine that the judge in Doe and Roe thinks that, on the proper understanding of justice, everybody owes everybody else a duty of care. Roe might well feel aggrieved that the judge has paid no attention to the past decisions that make proximity a condition of liability, or which exempt people in his profession from being under such a duty. It will be of little consolation to him that the judge has respected any relevant institutional considerations in past cases; for in common law negligence cases such as his, the decision will typically be dominated by considerations of substance.

I am conscious that I may be misreading Kyritsis. Perhaps, contrary to what I have been saying above, his judge in Doe and Roe is bound to heed both the considerations of institutional design and content contained in past political decisions. The judge's role in the Joint Project of

\footnotetext{
${ }^{10}$ Kyritsis answers this and other 'no constraint' objections with great skill in ch 3 .

11 For a similar objection, see TRS Allan, 'Judicial deference and judicial review: legal doctrine and legal theory' (2011) 127 L.Q.R. 96-117
} 
Government gives him this duty.

As a participant in this Project, he must respect not only the relative institutional competences of courts and political decision-makers, but also the substance of what others institutions decide. On this view, the judge must tolerate sub-optimal standards of justice in order to honour the extant separation of powers settlement. This understanding of Kyritsis certainly makes for a better fit with common law reasoning. But I think his accentuation of institutional over content considerations misses something important about the relevance of past political decisions to legal rights and duties. It misses the direct importance to a political community of its choices about justice - as opposed to the indirect importance that Kyritsis attaches to those choices. ${ }^{12}$ This is to say that the principles of negligence on which the judge relies in Doe and Roe command their allegiance, not just because other courts in the relevant judicial hierarchy have relied on them in the past, but because the application of those principles affords Doe and Roe a particular form of equality before the law.

Something like the rival view at which I have just hinted can be found in Dworkin's theory of law as integrity. ${ }^{13}$ For Dworkin, the adherence by courts to the substantive principles embedded in past decisions is not incidental to the pursuit of some greater project; this adherence embodies a value in itself. It is an expression of equal concern and respect for all citizens. A state treats its citizens as equals when, in circumstances of deep disagreement about what justice requires, it extends to them a single, coherent vision of justice. This is not to push institutional considerations to the margins. Judges and citizens disagree as much about separation of powers as they do about justice. Equal treatment therefore requires a commitment to the principles of justice (content) and fairness and procedural due process (institutional design) underlying past decisions.

Kyritsis makes many compelling objections to legality as integrity. I think he is correct to identify a 'mismatch' between legislative and adjudicative integrity, and the problems that this causes for a Dworkinian theory of separation of powers (101). For now, I shall deal with another of his objections. The objection is this: that the value of integrity is either weak or redundant because it captures inherent features of moral reasoning and justice such as consistency, coherence and nonarbitrariness (110). According to this objection, if we want people to act with integrity, we might as well 'enjoin [them] to be just' since each principle of justice 'requires consistency on its own terms'. ${ }^{14}$ Indeed, this is the very injunction that Kyritsis lays down for judges. I think there are two problems with this objection. First, it fails to distiguish between two very different situations: the situation of an individual deciding what justice requires, and the situation of a collectivity of judges and officials who disagree about justice making the same decision. In the former case, integrity will admittedly have little role to play: if the individual strays from their theory of justice, they have violated justice not integrity. But the latter case is more complex. If one judge is obsessed with equality, and another judge is obessed with liberty, both judges may act consistently, coherently, and so on in their decisions, but they will not respect political integrity. In the face of deep disagreement, political integrity requires that they suppress their own theory of justice in favour of the theory that provides the best justification for past decisions in that community. That involves acting consistently, but not in the weak sense that Kyritsis describes. Secondly, if it is for every judge to decide for herself the meaning of justice, then there is a danger that institutional considerations - central to Kyritsis's argument - will cease to be an genuine constraint. For Kyritsis, remember, judges should decide in accordance with justice unless there are genuine institutional reasons to do otherwise. If institutional considerations do not pass the threshold set by justice, then they are not binding (113). The difficulty here is that each judge will set a different threshold according to their own theory of justice. Suppose that an Act of Parliament does exempt people in Doe's category from negligence liability. A judge who espouses some extreme form of egalitarian justice may decide that this legislation is too

12 We can perhaps find a useful analogy here with a criticism that Kyritsis's makes against Waldron. By insisting on majority decision-making as the basis of political legitimacy (see Waldron, above $\mathrm{n}$ 10), says Kyritsis, Waldron ignores the importance of respecting the choices that people make about their institutional settlement (78). My point is that we similarly need to respect the choices that people make about their justice settlement.

${ }^{13}$ See Dworkin, above $\mathrm{n}$ 4, chs 6 and 7. I draw very broadly on the argument of these chapters in the paragraph corresponding to this footnote.

14 See Denise Réaume, 'Is Integrity a Value? Dworkin's Theory of Legal Obligation' (1989) 39 University of Toronto Law Journal 380, 392. Similarly, see Scott Hershovitz, 'Integrity and Stare Decisis' in Hershovitz (ed), Exploring Law's Empire: The Jurisprudence of Ronald Dworkin (Oxford, Oxford University Press, 2006) 119, 114. 
unjust to respect. That picture is far removed from the central case of common law judicial decisionmaking.

Kyritsis is, of course, alive to the issue of disagreement. He replies that disagreements about integrity are likely to be no less controversial than disagreements about justice (112). Even if a particular judicial decision accords with integrity, and is therefore legitimate, a citizen may believe otherwise, in which case integrity 'loses its alleged advantage over the justice-based account' (112). He may be right about the beliefs of citizens, but this seems to miss the point. As a legal interpretivist, his aim is to identify the metaphysical determinants of the law as a source of political legitimacy (20). The advantage we are interested in, I take it, is the treatment people actually receive under the law, rather than the treatment that people perceive they receive. I have suggested in the most sketchy fashion that a model of legality as integrity gives Doe and Roe the better prospects for equal treatment. Kyritsis's model of legality as separation of powers arguably places them at the mercy of judges' individual theories of justice.

I have not examined in any detail Kyritsis's Joint Project of Government as the basis of political legitimacy. That would require a separate review. Suffice it to say that this Project assumes a collaborative attitude on the part of courts vis-a-vis the other branches of government (58). It supposes that courts and the legislature do - and are bound to - respect the powers assigned to them by relevant institutional principles (74). I fear that this may give too rosy a picture of interinstitutional relations in contemporary constitutions. Judges and legislators can have radically different views of their respective powers. In place of any sort of joint project, one finds antagonism and distrust. In these circumstances, perhpas the most we can hope for is the weak form of cooperation described by Bratman as 'mutual responsiveness'. ${ }^{15}$ The implications of this line of argument for Kyritsis's interpretative theory must wait for another time.

\section{CONCLUSION}

Shared Authority is an outstanding contribution to debates in and about legal and constitutional theory. It is testament to the quality of the book that it will attract as much critical interest from signed up legal interpretivists as it will from those who reject interpretivism altogether. In this review, I have sprinkled the seeds of a few challenges to Kyritsis's theory of legality as separation of powers from within the interpretative architecture. Specifically, I have attempted to highlight some reasons an interpretivist may have for favouring Dworkin's theory of law as integrity over Kyritsis's imaginative revision of it.

15 See Bratman, above n 5, 327 